\title{
POETIC BOUNDARIES OF OPEN CITIES ${ }^{1}$
}

\author{
Magdalena Barbaruk \\ University of Wroclaw, Poland \\ magdalena.barbaruk@uwr.edu.pl
}
This paper was funded from the Polish National Science Centre research grant
"Trajektorie słowa. Kulturowe oddziaływanie Amereidy"
(Trajectories of the Word: The Cultural Influence of the Amereida)
No. 2017/25/B/HS2/00453.

The author argues that in order to fruitfully explore the city within the cultural-studies framework one must first accurately define the city as an object of knowledge, which only highlights the problematic nature of the boundaries of the city. The article foregrounds the key role of the cultural heteronomy of the city, which overrides its civilisational heteronomy. Culture, which the Polish culture scholar Stanisław Pietraszko understands as a way of being in accordance with values, is the determining factor in the identity of the city and is manifest in the openness and fluidity of its limits. Central thematic concern lies in literary "prostheses" of cities, which are needed in places inhabited by migrants, the colonized, "the subjects homesick" for "their" cities. Fiction and poetry bear a crucial ontological and axiological city-making responsibility, as demonstrated in the author's previous studies on Quixotic La Mancha and reconfirmed in this paper on the example of the Latin American Amereida, a group of architects, poets and artists. The author examines their 1965 journey from Chile, called Travesía (The Crossing), whose aim was "poetic dwelling" in America. During the journey, they performed poetic acts referred to as phalènes, whose idea grew out from an earlier trip to Paris and urban poetic practices in Santiago de Chile. As the pampa and Patagonia became a symbol of absolute modernity, the realisation is prompted that the modernity of the city-text can be "re-written" onto a non-urbanised space. The article ends with a glimpse of the utopian Open City (Ciudad Abierta), which the Amereida founded on the Pacific coastal dunes in 1970 in order to live there, work and teach students of the Faculty of Architecture of the Catholic University of Valparaíso. The pursuits undertaken in the city show that what is poetic is "open," long-lasting and communal.

Keywords: Amereida, the Open City (Ciudad Abierta), travesía, city, city limits / boundaries, modernity, culture, values, South America.

DOI 10.23951/2312-7899-2019-1-32-43

\footnotetext{
${ }^{1}$ Transl. into English by Patrycja Poniatowska.
} 
But we are men who love Malevich's white on white, and we know that there is no novel, science, art or metaphysics that can touch the beauty of unattainable frontiers. And this is what the Pampa is like ${ }^{2}$.

A real, albeit currently often ignored, challenge every research faces is how to accurately define the object of research, which primarily entails distinguishing it from the material of research. Today, reflection on ontology tends to be clipped just to the opening sentence of a lecture, as the cultural studies scholar Dorota Wolska observes [Wolska 1991, 58]. Stanisław Pietraszko subscribed to an entirely different approach as he founded Poland's first Culturology Department at the University of Wrocław in order to establish what culture is and in what ways it differs from the rest of the human world. Undoubtedly, he made what very few people care about now into his chief object of inquiry.

My argument in this paper, which focuses on the city and thus seeks to define the object of my interest, is influenced by three fundamental factors. One of them involves my theoretical framework, which is intimately linked to the education and training I received at the Department of Culturology at the University of Wrocław. In this framework, culture is understood to be an axiotic space or an autonomous order of human reality, whereby the boundaries between culture, society and civilisation are highlighted. The second factor that strongly affects my perspective is the fact that I live in Wrocław, a city whose current identity has been shaped by post-war refugees and settlers who had been displaced from other parts of Poland. The third factor is exemplified in my long-standing preoccupation with the phenomenon of SouthAmerican cities, which have also been formatively affected by migrants, newcomers and refugees. All these three aspects involve thinking about borders even though in each of them borders denote a slightly different thing.

Cities which are built by "strangers" have problematic, rather vague boundaries, which is in and of itself an ontological observation. The foundations on which the life of such cities is based are susceptible to being eroding by irremovable nostalgia. This nostalgia is of cultural and, as such, non-individual nature. I do not specify the concept of "refugees" or "migrants" comprehensively here, but without a doubt, the people on whom I focus in this paper are - unlike today's wanderers - for the most part Europeans or have European roots. The life of the Israeli writer

\footnotetext{
${ }^{2}$ Amereida 1986, 52.
} 
Amos Oz can be usefully evoked here as an excellent case in point. His parents were born in pre-war Poland: mother in the town of Równe (present-day Ukraine) and father in Vilnius. At their new home in Jerusalem, where they moved in the 1930s, even "tea, which was served European-style in china cups, smelled of homesickness" [Sękalska 2019]. The two pictures the family kept in their book-filled flat showed European landscapes. The picture of interest to me envisioned a small town on a river, with bridges and towers. This image shaped Oz's idea of what a real (because European) city was like. Jerusalem could not be such a city. After his mother's suicide, Oz settled in Kibbutz Hulda as a gesture of protest against the world of his father (a world of libraries, literary narratives and intellectual circles). He believed that the close acquaintance with the four hundred other residents of the kibbutz had afforded him a better insight into human nature, regarding what is believed most distinctive about humanity (love) as well as least distinctive about it (e.g. genetic heredity), than any knowledge he could possibly have gained if he had spent his life in a big city or, for that matter, trodden all the paths of South America [Oz, 2016]. Despite contesting the tradition of his parents, Oz wrote Touch the Water, Touch the Wind, a novel whose action is set in the Polish "town of M." The dreamlike vision of this town was unmistakably inspired by his mother's tales about Równe.

Nostalgia stirred by the experience of "lack" in a new city makes this city more liquid, mobile, displaced and elusive. The ontological deficits are remedied by various means, among which axiological "prostheses" embodied in literature are of salient interest to me. Heterogeneous cities of this kind are an essential symbol of our times, but it takes special tools to be able to discern them. They are "open" cities, where openness refers not only to the unimpeded fluxes across the networks that make them up, but also to "being open" by poets for dwelling, as envisioned by Friedrich Hölderlin and Martin Heidegger, who reinterpreted Hölderlin's dictum ${ }^{3}$.

In order to "read" the city, that is, to make it into an object of interpretation, one must know how to delimit it. This means that one must have what José Ortega y Gasset pithily called an anatomical talent [Ortega y Gasset 1993, 85], without which one cannot see the city as a genuine whole. Such a disposition is crucial, for it turns out time and again that

\footnotetext{
${ }^{3}$ The reinterpretation concerned Friedrich Hölderlin's celebrated statement that "poetically, man dwells on this earth". Hölderlin believed that the role of poetry is to channel human cooperation rather than to aesthetically represent goods of cultural. The making and understanding of poetry are collective and practical acts.
} 
although we just want to pluck a tiny leaf, we end up having to take the entire tree with roots, as Ortega y Gasset metaphorically observed discussing the distinctiveness of the interpretation of paintings. The city is first and foremost an entity of cultural nature, yet over the ages heteronomies of cities have been configured and hierarchised in multiple different ways. Felipe Fernández-Armesto evoked Santillana del Mar in order to demonstrate how profoundly dubious the traditional criteria of civilisation, therein "urbanity," were. The small Spanish town (with the Cave of Altamira on the outskirts) challenges the notion of identifying the urban with the post-agrarian: "Economics $<\ldots .>$ do not make a city: only the state of mind of the citizens can do that. In Santillana del Mar there are cattle grids in the streets, but civic pride frowns from every crested stone façade" [Fernández-Armesto 2002, 29]. It is difficult to define what the city is in civilisational terms because it is culture that provides the axial order of the city's identity ${ }^{4}$.

The cultural heteronomy of the city is particularly pronounced in cities which are described as "literary" or "utopian". Bronisław Baczko insists that actually all Cities of Utopia are "literary cities". Whether they can be built or whether they are thoroughly imaginary does not matter; what does matter is that to represent and understand them one does not need plans or drawings, for tales alone will do: “The Cities of Utopia are thus literary also in the sense that none of their aspects exists outside the word. The entire city, with all its dimensions, can be narrated, at most such story-telling "would take volumes upon volumes»" [Baczko 2016, 321]. With utopian cities, the conundrum of their boundaries is ostensibly redressed owing to their spatial demarcation, which often entails enclosure within a fixed geometrical figure. If we realise that utopian projects implemented in various settings, particularly in the New World, should be seen in conjunction to the European tradition initiated by Thomas More's Utopia, we will notice that the boundaries of the phenomenon we want to "read" have become porous, if not fissured ${ }^{5}$. This is also influenced by framing utopias as a "verb" rather than as a "noun", that is, by emphasising the practising, enacting and experiencing of utopia. On this model, utopias are not simply farremoved constructs, but they can make up a relevant component of ways of life, given their interrelatedness with values which are invested with a binding power.

\footnotetext{
${ }^{4}$ We can wonder today if cities, which are being ousted by "valleys" (e.g. the Silicon Valley), should perhaps be regarded as post-cultural.

${ }^{5}$ Interestingly, Utopia was written in 1516, the same year that the term "ghetto" was first used in Venice. The two words refer to spatially isolated places and have acquired very ominous overtones indeed since then.
} 
Between 2012 and 2014, I devoted a good part of my research to exploring the Spanish Route of Don Quixote ${ }^{6}$. I particularly focused on its present-day condition, which is heavily impacted by the new, not infrequently ruthless mechanisms of the cultural industry. In this venture, I was mainly driven by the idea of investigating the phenomenon of the literary route comprehended as a way of life and a pursuit of fictionderived values which come forth in the landscape $\mathrm{e}^{7}$. The phenomenon is relatively autonomous of changes in nature, material alterations, national determinations and historical transformations. As the characters and the scenery of Cervantes's novel were erected into cultural myths, a number of small towns of La Mancha were transfigured into literary places - lugar de la Mancha - which vied for the status of Don Quixote's village, which the narrator of the novel was not eager to recall. The borders of La Mancha were thus drawn by one book, whose axiological agenda of universal justice, freedom and everybody's right to be "the son of one's own works" turns La Mancha into a locus of utopian practice. As a result, La Mancha became an affective literary place, which only confirms the agency of literature in the sphere of identity, urban design, landscape, cultural memory, etc. [Barbaruk 2018].

Few are the developments which equally emphatically exemplify the power of the word over space, equally irrefutably assert the impact of literature on cultural realities, equally closely interlace ontology and axiology and equally absolutely make the existence of a thing hinge on whether this thing embodies particular values. At an exhibition in the Museo de Bellas Artes (Chile), I saw photos of the Travesía, a radical poetic journey across South America undertaken in 1965. For me, the discovery of the Amereida ${ }^{8}$ - also called the School of Valparaíso a group founded by the architect Alberto Cruz Covarrubias and the poet Godofredo Iommi, was like finding another link of the chain originating in the wanderings of Don Quixote.

The Amereida strove to effect a cultural change by means of poetic tools. This requires a very particular understanding of the functions of language, which are neither only reduced to communication nor elevated into an absolute autonomy as envisaged by Stéphane Mallarmé. Although, in many senses, the poetics of the Amereida dovetails with modern avant-garde varieties of diction (e.g. Surrealist or Constructiv-

\footnotetext{
${ }^{6}$ The Polish National Science Centre research grant "Mancza jako ziemia literatury. Kulturowy status tras literackich" (La Mancha as the land of literature: The cultural status of literary routes), No 2012/04/S/HS2/00558.

${ }^{7}$ I discuss the values that demarcate the axiotic space of Quixotism in my book "The Long Shadow of Don Quixote", transl. into English by P. Poniatowska (Frankfurt am Main 2015).

${ }^{8}$ The name "Amereida" is a compound combining "America" and "Eneida" (i.e. Aeneid).
} 
ist), it can hardly be equated with them due to its unique axiological and ontological investment. Specifically, the Latin-American project is nurtured by the deficit I evoked above, by the desire for identity, the dearth of places (and the surplus of space), the necessity to "open" reality in order to truly dwell in it. Briefly, the project is at the same time a vision, an enactment and a realisation of utopia.

The travesía, i.e. the crossing from Tierra del Fuego through the Chilean and Argentinian interior up to Bolivia, which spanned one and a half months (from $30^{\text {th }}$ July to $13^{\text {th }}$ September 1965), was an ambitious and challenging venture. Many of its philosophical and artistic goals can certainly be construed as a decolonising, subversive interception of Columbus's foundational "gesture" and of the topos of the urgent "reinvention of America" [Pratt 2008]'. The improvised undertakings charted a zig-zagging route which was composed of places woven into density by the poetic word and action. Ephemeral artefacts were supposed to symbolise the first inhabitation of the continent. The travellers themselves claimed that as long as things remained unnamed, they were ungraspable while the "poetic act $<\ldots$. just like cattle branded with a red-hot iron <...> brings names to things" [Arce de 2003, 15]. Given this, the first travesía inaugurated a new reality and was a poetic journey not only because a lot of poems by, for example, Nerval, Apollinaire, Baudelaire, Keats, Rimbaud and Lautréamont were read on the way.

The ten-people group sought to move away from the coastline of the continent, which they associated with the conquista, and set themselves the goal of discovering the unknown "interior sea." There is no one overriding reason why the journey commenced in the town of Punta Arenas at the gates of Tierra del Fuego ${ }^{10}$. Of course, it made sense in

\footnotetext{
${ }^{9}$ The role of this topos in producing the image of South America is studied by M. L. Pratt in her Imperial Eyes: Travel Writing and Transculturation. The rise and the durability of this image were instrumentally affected by the explorations and writings of the German geographer A. von Humboldt.

${ }^{10}$ Tierra del Fuego and Patagonia are places suffused with fiction and fantastic tales, many of which concern extraordinary peoples and locations, such as the "gold" kingdom of Trapananda purportedly reached by Arias Pardo Maldonaldo. Building on this image, Luis Sepúlveda wrote about the "eighteenth Patagonia lying championships," broadcast by the local radio: "Here, in this land, we lie to find happiness. But no one confuses lies with deceit" [Sepúlveda 2003, 78]. Tierra del Fuego is also used as the prototype of mysterious, dystopian W Island and cast as a place of fantasy where everything and anything may happen in Georges Perec's autobiographical book. The book's concluding passage reads: "I have forgotten what reasons I had at the age of twelve for choosing Tierra del Fuego as the site of W. Pinochet's Fascists have provided my fantasy with a final echo: several of the islands in that area are today deportation camps" [Perec 1988, 164]. Notably, there is a profound similarity between Perec, $\mathrm{Oz}$ and those who fashioned geopoetic narratives as a result of grappling with problematic identities (the acute "lacuna" in Perec's personality was caused by the "disappearance" of his Jewish parents in extermination camps when he was a young child).
} 
terms of cartography (i.e. of the idea of going along the vertical axis of the "reversed map"); at the same time, America's southern edge notably resembles a cosmopolitan city (today's population of Tierra del Fuego consists of 70,000 people of chiefly European descent). During the arduous crossing of Patagonia, the travellers encountered people of various nationalities who talked about their homesickness for Europe and nostalgia for the past, questioned their life in America as pointless and bewailed their enforced "in-betweenness". The diary entry of $4^{\text {th }}$ August describes Christos Varnava, a café owner from Punta Arenas: "A Cypriot who is sick, even dying of nostalgia, and in a few days is going to London for treatment. He approached us one day and, chatting, said that he had 'made a mistake' coming to America and then to Punta Arenas, as his brother and other family had remained in England" [Amereida 1986, 5]. In response, the group made a drawing in front of his cafe, wrote a poem saying that he "did not make a mistake" and gifted it to the Cypriot.

The group adopted a symptomatic strategy regarding the main square of Punta Arenas. It was "the square of nostalgia, with trees planted at equal intervals by a gardener" [Amereida 1986, 44]. They knew they could not replant the trees, but they wanted to transform the square - to "attain the unattainable" - by writing a poem that would serve as a study of the plain, the cold and the wind. The poem, as they put it, is not supposed to "reflect the and" or to be "a rising sun"; rather, it is supposed to become a sun that will "touch again the space of the square to which a poem has been added" [Ibid., 44].

The events and passages cited above speak to the influence of Hölderlin's ideas on the philosophy espoused by the Amereida. "The gift of opening" is made possible precisely by poetry as only the poetic word can bring about lasting changes in the world. The importance that the Amereida attributed to language is vividly illustrated by the contrast between the respective attitudes displayed by the Cypriot and a certain sheep-breeding Englishman. After the show of shearing and slaughtering one sheep, they drove with him to a hill: "Up there, Clifton opens up to memories. Onas and Tehuelches, Puerto Natales and Punta Arenas, Menéndez, English Barnel, and English Dicks, and English... With us all around him. Up on the hilltop. Godo begins to call this hill the 'Clifton Hill' from now on" [Ibid., 9]. The boundaries that circumscribed Clifton's world were set by the English language, which visually materialised when he set his foot on the hilltop. The boundaries of

Crucially, the influx of fictionality into the real is bound up with the tragic dimension intrinsic to the life of an individual hurled into History. 
this world were "imprecise but accurate"11. The difference between the Cypriot and the Englishman lay in the semantics of the language which is used in a foreign territory: "Christos Barnabas ${ }^{12}$, dying, vainly looking for the lost shores so as to touch himself again. The living desert of adventure and an émigré who'll remain an émigré for ever. On the other hand, Clifton carries a precious temple in himself. What temple? <...> It's about how he treats the language he speaks, the imperial English which harbours sounds and meanings distinctive to all and any remoteness" [Ibid., 46].

The inhabitants of Tierra del Fuego and Patagonia are beset with nostalgia, which immobilises not only the present but also history. Does one have to move to a city in order to become modern? South American cities appear in the diary as physically and metaphorically distant. A lot of thought is devoted to them, and a lot of talk. The Amereida's diary notes that the city and its boundaries are a "matter of rhythm" - "of the distance and its pulsations".

What certainly deserves to be mentioned is the conclusion the participants in the travesía drew from their stay at Puelches, where they came on $25^{\text {th }}$ August after getting lost on the way: "We have reached the Puelches checkpoint, and we're going to have a cup of coffee at a shop. The interlocutor is talking incessantly, joking all the time. On the map, Puelches is marked as a big city. Having arrived there at night, there is nothing. Only this shop. A big building" [Ibid., 18]. The town's population had started shrinking due to a lack of water caused by the construction of the Nihuil dam in Mendoza, dropping finally from 700 to 270 people. What remained of the pervious form of life was the inadequate urban infrastructure, symbolised by the never-opened school and the teachers waiting for the Argentinian flag requested from Buenos Aires: "It is the strangest feeling ever: there's a police station, a court of peace, a registry office, a post office, an airfield, a weather station, a public phone, but there's no town (pueblo)" [Ibid., 19]. The school was opened with teachers and students in attendance, whereby the Amereida performed several poetic acts. Having left Puelches, they concluded that although "Puelches was the pinnacle of Phalène", they had actually failed; "They had their own dead, San Martin and Belgrano" [Ibid., 19]. The group did not abide by its ow rhythm, so the words could not capture Patagonia. They wrote down in the diary:

\footnotetext{
${ }^{11}$ Clifton told then a story about an Indian chief who was looking at the rounded horizon from a hilltop: "What his eyes could see made the boundaries of his tribal territory, boundaries imprecise but exact at once" [Amereida 1986, 15].

${ }^{12}$ In the text, the Cypriot's name is spelled in two different ways: "Varnava" and "Barnabas."
} 
"[Godo] said that he'd given up on his poem about Patagonia. The previous night we were talking about going to Buenos Aires, but now the failure in the face a situation as complicated as the one at Puelches urges us to recognise our limits. [Godo] proposes continuing our crossing of the desert. We told the people of Puelches to stay while they should perhaps leave" [Ibid., 20].

I believe it makes sense to juxtapose this somewhat enigmatic entry with another one, at the end of the diary: "travesía subtly undermines almost all of our notions. First of all, it leads architecture itself towards abstraction greater than the number. Woven out of the poetic word, architecture opens up to unexpected rhythms. What are walls, for example? What are ceilings? Is there a way to dwell without them? <...> History does not have to be a recollection, but a narrative about things happening, about foundational acts, always full of different, unthinkable architecture" [Ibid., 57]. A similar thing concerns the city; during the journey, modernity associated with the city was separated from the semantics of the city and paired with the "text" of the pampa and Patagonia. The group's diary foregrounds the "absolute modernity of Patagonia" [Ibid., 14].

In the part of The Practice of Everyday Life which discusses the production of the city through practices, Michel de Certeau avails himself of a suggestive image of the city which is foreign to him. This image is a panoptic view of New York one could see from the top of the World Trade Center. New York then turned into a legible, mistakenly understood "text". Certeau's line of thought is close to the following insights of the Valparaíso group:

"Because of its height, a city can separate from itself in order to contemplate itself. I wonder what it may be like in the Patagonian pampa. How does it look at itself? And it looks at itself from the ground level rather than from an altitude. It is its own height. Therefore, work and contemplation do not correspond to two different moments. Hence, while working you don't need to raise your eyes to stare into the distance and contemplate. Work and contemplation as one and the same moment. Nostalgia comes when the eyes stare into the distance, it does not arise because of working on the pampa. A land without such nostalgia. A modern land - due to this - so modernity is a non-severance of contemplation from work" [Ibid., 53].

To move away from the coastline, to avoid cities, to go across the pampa, the field, the wilderness, to resist nature, to draw a poetic trail with phalènes without expecting them ever to be seen - all this means being "absolutely modern" [Iommi 1982]. We must remember, however, 
that poetic drifting through the "interior sea" had its source in ramblings across Santiago de Chile ${ }^{13}$. When Iommi and Cruz met at a metropolitan advertising agency in 1941, they started devising methods of making this "poetry in action" a reality. Cruz would take architecture students out of lecture halls to look at the streets full of speeding cars. The very idea of phalènes came into being in Paris during Iommi's trip to Europe (1958-1963). In this framework, a phalène meant an improvised poetic act which was performed in public with the participation of artists and passers-by. This kind of "poetry in action" was inspired by Surrealism, Symbolism and Situationism ${ }^{14}$. Phalènes were formatively informed by the call to free poetry from the script. In Iommi's view, the city was a space that promoted unexpected, meaningful events which are produced by all ${ }^{15}$. Cruz and Iommi were the "sons" of modernity which was becoming a reality in post-war big cities of Latin America. "The path to decolonization $<. . .>$ runs not around, but through the codes of modernity" [Pratt 2008, 230], through metropolises, through Paris and Europe.

In the America of military dictatorships crossing the borders was a very difficult enterprise. This predicament was addressed in the writings of Luis Sepúlveda, a Chilean author and a communist activist who, having spent two and a half years in prison in Temuco, decided to leave for Europe or Africa. It was practically a sheer impossibility for a person with the enigmatic letter $\mathrm{L}$ in the passport. "Drifting" across the continent, Sepúlveda came to La Quiaca, a small city on the border with Bolivia: "The essential thing was to wait out, in drift, the time of fear, the way that ships at sea wait out coastal storms, drifting. <... In every city I stopped at, I visited old friends or made new ones. Barring very few exceptions, everybody I met was steeped in the same bitter and depressing aura: people lived in fear and for fear" [Sepúlveda 2003, 32]. After lying face-down on the platform for a few hours, Sepúlveda eventually did not board the train going over the frontier to La Paz, prevented by the Bolivian military. The Amereida group admittedly managed to cross the border with Bolivia, but after a few incidents involving the army, they decided to terminate their journey as a free, poetic travesía proved impossible there. Santa Cruz de la Sierra, the new poetic capital they designated for the continent, was not reached.

\footnotetext{
${ }^{13}$ The metaphor of drifting on the sea was pivotal to psychogeography practised by Parisian situationists.

${ }^{14}$ Usually cited among the sources of inspiration are W. Blake, Novalis, S. Mallarmé, A. Rimbaud, G. Apollinaire, Ch. Baudelaire, A. Breton and G. Debord.

${ }^{15}$ This is a reference to Lautréamont's insistence that "poetry should be made by all, not just by one".
} 
After their return, Cruz and Iommi engaged in the University Reform of 1967. As a result, the Faculty of Architecture of the Catholic University of Valparaíso obtained almost three hundred hectares of dunes on the Pacific coast (Ritoque), where they inaugurated the Open City (Ciudad Abierta) in 1970. There they could live, work and educate students. What are the boundaries of "open" cities have? And of "closed" cities? The limits of the Open City are paradoxically demarcated by "objective," implacable nature while at the same time its autonomy is safeguarded by the fragile independence of the university as an institution founded for the sake of the disinterested search for truth and unfettered scholarly research.

In order to enter the City, one must go through the gate, which is an "intuitive phenomenon of transition" [Panas 2017, 13], reminiscent of the Heideggerian Lichtung. Within the City, poetic phalènes take place which "open" the space and are the cornerstones of all buildings. Some of them are of very special nature. Within a two-year project of constructing the Casa de los Nombres as part of the $40^{\text {th }}$-anniversary celebrations of the Architecture Institute in Valparaíso (1992), a structure was erected on the dunes by four hundred people. Reading bodies were used to fix the location of twenty-nine concrete pillars. During the performance of the poetic act, the relationship was established between the reading of a verse of poetry and the length of the reader's wandering; then the tall poles were rammed into the ground. The structure was covered in black meshwork and polyethylene membrane. The boundaries of this house combine the ostensible opposites of fleeting reading and durable building materials. They are poetic boundaries par excellence.

\section{REFERENCES}

Amereida 1986 - Amereida II Bitácora. Viña del Mar, 1986.

Arce de 2003 - Arce de R. P. So far yet so near: The Open City and the Travesías. Valparaiso School: Open City Group. Ed. by R. Rispa, R. P. de Arce, F. P. Oyarzún. Montreal, Kingston, 2003. P. 13-17.

Baczko 2016 - Baczko B. Światła utopii. Warszawa, 2016.

Barbaruk 2018 - Barbaruk M. Sensy błądzenia. La Mancha i jej peryferie. Kraków, 2018.

Certeau de 1984 - Certeau de M. The Practice of Everyday Life. Transl. into English by S. Rendall. Berkeley, Los Angeles, London, 1984.

Fernández-Armesto 2002 - Fernández-Armesto F. Civilizations: Culture, Ambition and the Transformation of Nature. New York, 2002. 
Iommi 1982 - Iommi G. Hay que ser Absolutamente Moderno. Valparaíso, 1982.

Ortega y Gasset 1993 - Ortega y Gasset J. Velázquez i Goya. Trans. into Polish by R. Kalicki. Warszawa, 1993.

Oz 2016 - Oz A. Amos Oz w Trójce o swoim życiu i twórczości: Rozmowa z M. Nogasiem. Trójka. 2016. March 10. URL: https://www. polskieradio.pl/9/396/Artykul/1592601,Amos-Oz-w-Trojce-o-swoimzyciu-i-tworczosci.

Panas 2017 - Panas W. Brama. Konteksty. Polska Sztuka Ludowa. 2017. 3 (318). P. 9-14.

Perec 1988 - Perec G. W, or the Memory of Childhood. Trans. into English by D. Bellos. London, 1988.

Pratt 2008 - Pratt M. L. Imperial Eyes: Travel Writing and Transculturation. London, New York, 2008.

Sękalska 2019 - Sękalska D. Amos Oz - Opowieści o miłości i mroku. Dwójka. 2019. February 3. URL: https://www.polskieradio.pl/8/2382/ Artykul/2257044,Amos-Oz-\%e2\%80\%93-opowiesci-o-milosci-imroku.

Sepúlveda 2003 - Sepúlveda L. Express Patagonia. Trans. into Polish by A. Elbanowski. Warszawa, 2003.

Wolska 1991 - Wolska D. Czy twórczość stwarza wartości? Prace Kulturoznawcze. 1991. 2. P. 57-63.

Материал поступил в редакцุию 18.02.2019 